\title{
ANALISIS ELASTISITAS TIGA BAHAN PANGAN SUMBER PROTEIN HEWANI DI INDONESIA
}

\author{
Daru Wahyuni, Losina Purnastuti, \& Mustofa \\ Universitas Negeri Yogyakarta, Indonesia \\ Email:daruwahyuni@yahoo.co.id
}

\begin{abstract}
Abstrak: Analisis Elastisitas Tiga Bahan Pangan Sumber Protein Hewani di Indonesia. Penelitian ini bertujuan untuk menganalisis perilaku permintaan rumah tangga atas tiga sumber protein hewani (ikan, daging sapi, dan daging ayam) dikaitkan dengan karakteristik rumah tangga yang berbeda dan menganalisis respon rumah tangga di Indonesia terhadap perubahan harga dan pendapatan pada konsumsi ketiga komoditas tersebut. Model yang digunakan untuk melakukan estimasi adalah model Almost Ideal Demand System (AIDS), dengan menggunakan data dari Indonesia Family Life Survey gelombang 4 (IFLS 4). Jumlah rumah tangga sumber data yang dianalisis dalam penelitian ini berjumlah 839 rumah tangga. Hasil penelitian menunjukkan secara parsial harga ikan, harga daging sapi, pengeluaran rumah tangga, wilayah geografi, dan jumlah anggota keluarga berpengaruh terhadap pangsa pengeluaran untuk produk ikan-ikanan, daging ayam, dan daging sapi. Elastisitas permintaan harga permintaan untuk ikan, daging sapi, dan daging ayam masuk dalam kategori inelastis, elastisitas pendapatan untuk daging sapi dan daging ayam masuk kategori elastis, dan ikan mempunyai elastisitas pendapatan yang inelastic.
\end{abstract}

Kata kunci: model Almost Ideal Demand System (AIDS), elastisitas harga permintaan, elastisitas silang, elastisitas pendapatan.

Abstract: Elasticity Analysis for Three Animal Protein Resources in Indonesia. This study aimed to analyze the behavior of household demand on three sources of animal protein (fish, beef, and chicken) were associated with different household characteristics and analyze the response of households in Indonesia to changes in price and income on the consumption of fish, beef, and chicken. Almost Ideal Demand System (AIDS) was adopted in this study, using data from the Indonesia Family Life Survey wave 4 (IFLS 4). Total number of the household analyzed in this study amounted to 839 households. The results showed that partially price of fish, beef prices, household expenditure, geographic region, and number of family members affect the share of expenditure fisheries products, chicken, and beef. The results implied that Price elasticity of demand for demand for fish, beef, and chicken were categorized as inelastic. While the income elasticity for beef and chicken were elastic, furthermore income elasticity for fish was inelastic.

Keywords: Almost Ideal Demand System (AIDS) model, demand price elasticity, cross elasticity of demand, income elasticity of demand.

\section{PENDAHULUAN}

Tingkat konsumsi rumah tangga merupakan salah satu komponen dalam pembentukan Produk Domestik Bruto (PDB) Indonesia. Perkembangan dari tahun ke tahun menunjukkan bahwa konsumsi rumah tangga selalu menjadi kontributor terbesar dalam pembentukan nilai PDB. Dalam 10 tahun terakhir (2001-2010) rata-rata pertumbuhan PDB mencapai 5,22\% dan 
disumbang oleh pertumbuhan konsumsi sebesar 3,17\% yang di antaranya berasal dari pertumbuhan konsumsi rumah tangga sebesar 2,56\% (Bank Indonesia: 2011).

Pengeluaran konsumsi rumah tangga digunakan untuk memenuhi berbagai pengeluaran konsumsi akhir atas barang dan jasa untuk memenuhi kebutuhan individu ataupun kelompok. Pengeluaran rumah tangga di sini mencakup pembelian untuk makanan dan bukan makanan di dalam negeri maupun di luar negeri. Perilaku rumah tangga dalam mengkonsumsi makanan dan bukan makanan untuk memenuhi kebutuhan sehari-hari merupakan salah satu hal yang dapat mencerminkan tingkat kesejahteraan masyarakat suatu negara. Pada umumnya semakin besar pengeluaran konsumsi rumah tangga yang digunakan untuk pembelian bukan makanan akan menunjukkan tingkat kesejahteraan rumah tangga tersebut yang cenderung semakin baik dan sebaliknya. Berdasarkan data mengenai persentase pengeluaran rata-rata per kapita sebulan menurut kelompok barang 2008 - 2011 yang dipublikasikan oleh BPS, secara umum dapat dikatakan bahwa konsumsi makanan dan bukan makanan rumah tangga di Indonesia tidaklah terlalu berbeda. Persentase pengeluaran konsumsi untuk kedua kelompok barang tersebut relatif berimbang.

Lebih lanjut, pengeluaran konsumsi untuk makanan di Indonesia masih dipilah untuk 14 kelompok makanan yaitu: padipadian, umbi-umbian, ikan, daging, telur dan susu, sayur-sayuran, kacang-kacangan, buahbuahan, minyak dan lemak, bahan minuman, bumbu-bumbuan, makanan dan minuman jadi, tembakau dan sirih, dan konsumsi lainnya. Berdasar data yang tersedia, pengeluaran konsumsi untuk makanan yang terbesar dialokasikan untuk makanan dan minuman jadi, diikuti kelompok padi-padian, dan kelompok makanan sumber protein hewani seperti ikan, daging, telur dan susu. Pengeluaran konsumsi rumah tangga kelompok makanan sumber protein hewani tersebut selama beberapa tahun terakhir cenderung meningkat.

Perkembangan pengeluaran rata-rata per kapita kelompok makanan sumber protein hewani seperti tersebut di atas, tentu merupakan hal yang menggembirakan mengingat selain pangan nabati, manusia juga memerlukan pangan hewani (ikan, daging, susu dan telur) sebagai sumber protein untuk asupan gizi dalam rangka menjaga kesehatan, memelihara stamina tubuh, dan meningkatkan kecerdasan otak. Berdasar data tersebut, sekilas akan bisa disimpulkan bahwa kesadaran rumah tangga Indonesia akan pentingnya konsumsi protein hewani semakin membaik, namun apabila dibandingkan dengan konsumsi produk yang sama di negara-negara lain, konsumsi protein hewani penduduk Indonesia tergolong sangat rendah. Pada tahun 2000, konsumsi daging unggas penduduk Indonesia hanya $3,5 \mathrm{~kg} / \mathrm{kapita} / \mathrm{tahun}$, sedangkan penduduk Malaysia mencapai $36,7 \mathrm{~kg}$, Thailand mencapai $13,5 \mathrm{~kg}$, Philipina mencapai 7,6 kg, Vietnam mencapai 4,6 kg, dan Myanmar mencapai 4,2 kg. Konsumsi telur penduduk Indonesia juga rendah, yakni 2,7 kg/kapita/tahun, sedangkan Malaysia mencapai $14,4 \mathrm{~kg}$, Thailand mencapai 9,9 kg dan Philipina mencapai 6,2 kg. Konsumsi susu masyarakat Indonesia juga sangat rendah, yakni sekitar $7 \mathrm{~kg} /$ kapita/tahun, sedangkan Malaysia sudah mencapai 20 
kg/kapita/tahun bahkan konsumsi susu masyarakat AS mencapai 100 kg/kapita/tahun (Rusfidra, 2013). Rendahnya tingkat konsumsi bahan makanan sumber protein khususnya protein hewani bisa jadi merupakan salah satu pemicu munculnya banyak kasus gizi buruk di Indonesia. Dalam jangka panjang, meskipun bukan satusatunya faktor penyebab, buruknya gizi masyarakat Indonesia tentu akan berpengaruh pula pada rendahnya kualitas sumber daya manusia.

Perilaku konsumsi rumah tangga atas suatu barang termasuk bahan makanan sumber protein hewani dipengaruhi oleh banyak hal seperti, tingkat harga, pendapatan, dan preferensi rumah tangga atas barang yang akan dikonsumsi. Preferensi tiap-tiap rumah tangga akan berbeda-beda karena adanya perbedaan karakteristik rumah tangga-rumah tangga tersebut misalnya dilihat dari perbedaan lokasi wilayah rumah tinggal, tingkat pendidikan ibu rumah tangga, jumlah anggota keluarga, kebiasaan, budaya, dan sebagainya. Rumah tangga dengan pendapatan, lokasi wilayah, tingkat pendidikan yang berbeda akan memiliki gaya hidup yang berbeda pula termasuk ketika menyediakan jenis bahan makanan bagi anggota keluarga. Dengan demikian perubahan harga bahan pangan sumber protein hewani dan pendapatan rumah tangga akan direspon dengan cara berbeda oleh masing-masing rumah tangga yang memiliki karakteristik yang berbeda tersebut.

\section{METODE}

Data yang digunakan dalam penelitian ini merupakan data sekunder. Data diperoleh dari Indonesia Family Life Survey (IFLS). Data yang dianalisis adalah data tentang pengeluaran konsumsi untuk bahan makanan sumber protein hewani dan harganya serta pengeluaran total rumah tangga di Indonesia. Data pengeluaran konsumsi bahan makanan sumber protein hewani yang tersedia dalam IFLS adalah pengeluaran konsumsi ikan-ikanan, daging sapi, dan daging ayam. Jumlah rumah tangga sumber data yang dianalisis dalam penelitian ini sebanyak 839 rumah tangga.

Kelompok bahan makanan sumber protein hewani yang dikonsumsi rumah tangga dalam penelitian ini terdiri dari ikan, daging sapi, dan daging ayam. Konsumsi produk-produk ini diduga saling terkait satu dengan lainnya. Oleh karena itu salah satu model yang sesuai dengan kondisi ini adalah model Almost Ideal Demand System (AIDS) yang dikembangkan oleh Deaton dan Meullbauer (1980). Bentuk akhir dari model ini adalah:

$$
w_{i}=\alpha_{i}+\sum \gamma \log P_{j}+\beta_{i} \log \left(\frac{X}{P *}\right)+
$$$$
\emptyset D 1+\delta D 2+\vartheta \text { HHSize }
$$

Di mana:

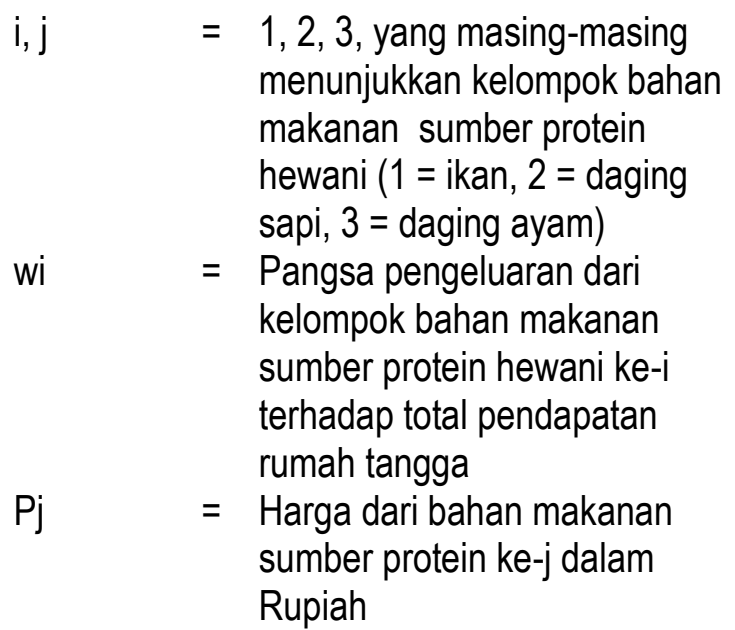




$$
\begin{aligned}
& \mathrm{X}=\text { Pengeluaran rumah tangga } \\
& \text { (Rupiah) } \\
& \mathrm{P}^{*} \quad=\text { Indeks harga Stone, dimana } \\
& \log \mathrm{P}^{*}=\Sigma \text { wi } \log \mathrm{pi} \\
& \alpha, \beta, \gamma, \theta, \varnothing,=\text { Parameter dugaan } \\
& \vartheta \\
& \text { D1 = Dummy wilayah, dimana: } \\
& \text { D1 }=1 \text { adalah kota } \\
& \text { D1 }=0 \text { adalah desa } \\
& \text { D2 = Dummy tingkat pendidikan ibu } \\
& \text { rumah tangga, dimana: } \\
& \mathrm{D} 2=1 \text { tingkat pendidikan } \mathrm{di} \\
& \text { atas SLTA } \\
& \text { D2 }=0 \text { tingkat pendidikan } \\
& \text { SLTA dan jenjang lebih rendah } \\
& \text { HHSize = Jumlah anggota keluarga }
\end{aligned}
$$

Sementara itu rumus yang digunakan untuk menghitung elastisitas permintaan peneliti mengadopsi formula yang disampaikan oleh Fujii, Khaled, dan Mark (1985) yang umum digunakan untuk menghitung elastisitas dengan pendekatan AIDS, sebagai berikut:

1. Elastisitas harga sendiri:

Uncompensated/Marshallian: $-1-\beta_{i}+$ $\gamma_{i} / w_{i}$

Compensated/Hicksian: $\quad-1-w_{i}+$ $\gamma_{i} / w_{i}$

Tabel 1. Ringkasan Hasil Estimasi Regresi Tiga Bahan Pangan Sumber Protein

\begin{tabular}{lccc}
\hline \multicolumn{1}{c}{ Variables } & $\begin{array}{c}\text { Estimasi untuk } \\
\text { Ikan }\end{array}$ & $\begin{array}{c}\text { Estimasi untuk } \\
\text { Daging Ayam }\end{array}$ & $\begin{array}{c}\text { Estimasi untuk } \\
\text { Daging Sapi }\end{array}$ \\
\hline Konstanta & $0,331^{* * *}$ & $0,405^{\star * *}$ & $0,264^{*}$ \\
Log harga ikan & $0,109^{* * *}$ & $-0,047^{* * *}$ & $-0,062^{* * *}$ \\
Log harga daging sapi & $-0,035^{* *}$ & $-0,142^{* * *}$ & $0,177^{* * *}$ \\
Log harga daging ayam & $-0,016$ & $0,166^{* * *}$ & $-0,150^{* * *}$ \\
Log Pengeluaran / Harga lkan & $-0,089^{* * *}$ & 0,011 & $0,078^{* * *}$ \\
Wilayah & $0,013^{*}$ & $0,015^{*}$ & $-0,029^{* * *}$ \\
Pendidikan Ibu & 0,019 & 0,020 & $-0,001$ \\
Jumlah Anggota Keluarga & $0,004^{*}$ & 0,002 & $-0,006^{* *}$ \\
\hline
\end{tabular}

\section{Keterangan:}

$$
\begin{aligned}
& * * *=\text { signifikan pada taraf signifikansi } 1 \% \\
& * * \quad=\text { signifikan pada taraf signifikansi } 5 \% \\
& * \quad=\text { signifikan pada taraf signifikansi } 10 \%
\end{aligned}
$$


tingkat pendidikan ibu rumah tangga. Hal ini mengandung arti bahwa secara parsial harga ikan, harga daging sapi, pengeluaran rumah tangga (sebagai proksi pendapatan), wilayah geografi, dan jumlah anggota keluarga berpengaruh terhadap pangsa pengeluaran untuk produk ikan-ikanan.

Parameter harga ikan bertanda positif artinya bahwa semakin mahal harga produk ikan-ikanan maka proporsi pengeluaran untuk produk ini akan semakin besar dan sebaliknya semakin murah harga produk ikan-ikanan maka proporsi pengeluaran untuk produk ini akan semakin kecil. Sementara itu dilihat dari tandanya parameter harga daging sapi bernilai negatif, artinya semakin mahal harga daging sapi, maka proporsi pengeluaran untuk produk ikan-ikanan akan semakin kecil dan sebaliknya semakin murah harga daging sapi, maka proporsi pengeluaran untuk produk ikan-ikanan akan semakin besar.

Dugaan parameter pengeluaran untuk proporsi pengeluaran ikan-ikanan memiliki tanda negatif. Hal ini berarti bahwa semakin tinggi pengeluaran riil (atau yang bisa juga dikatakan pendapatan) rumah tangga, maka semakin kecil proporsi pengeluaran yang digunakan untuk mengkonsumsi ikan-ikanan.

Berdasarkan hasil estimasi juga ditemukan bahwa ada perbedaan proporsi pengeluaran untuk produk ikan-ikanan antara rumah tangga di wilayah pedesaan dan perkotaan, sementara proporsi pengeluaran ikan-ikanan ternyata tidak ditentukan oleh tingkat pendidikan ibu rumah tangga. Lebih lanjut hasil estimasi juga menunjukkan bahwa semakin banyak anggota keluarga maka akan semakin besar pula proporsi pengeluaran untuk produk ikan-ikanan.

Kecuali pendidikan ibu rumah tangga, pengeluaran, dan jumlah anggota keluarga, parameter yang ditemukan dalam pendugaan konsumsi daging ayam, signifikan dengan taraf signifikansi antara 1\% - 10\%. Hal ini mengandung arti bahwa secara parsial harga ikan, harga daging sapi, harga daging ayam, dan wilayah geografi, berpengaruh signifikan terhadap proporsi pengeluaran untuk produk daging ayam.

Parameter harga daging ayam bertanda positif artinya bahwa semakin mahal harga daging ayam maka proporsi pengeluaran untuk produk ini akan semakin besar. Sementara itu parameter harga ikan-ikanan dan daging sapi bertanda negatif, artinya semakin mahal harga ikan dan harga daging sapi, maka proporsi pengeluaran untuk produk daging ayam akan semakin kecil.

Meskipun secara statistik tidak signifikan, dugaan parameter pengeluaran untuk proporsi pengeluaran daging ayam memiliki tanda positif. Hal ini berarti bahwa semakin tinggi pengeluaran riil (atau yang bisa juga dikatakan pendapatan) rumah tangga, maka semakin besar proporsi pengeluaran yang digunakan untuk mengkonsumsi daging ayam.

Berdasarkan hasil estimasi juga ditemukan bahwa ada perbedaan proporsi pengeluaran untuk daging sapi antara rumah tangga di wilayah pedesaan dan perkotaan, sementara proporsi pengeluaran daging ayam ternyata tidak ditentukan oleh tingkat pendidikan ibu rumah tangga dan jumlah anggota keluarga.

Dari semua persamaan permintaan dalam penelitian ini, ditemukan bahwa 
secara simultan semua parameter penduga signifikan secara statistik (ditunjukkan dengan nilai Prob. $F=0,0000$ ). Hal ini berarti bahwa harga ikan-ikanan, harga daging sapi dan harga daging ayam, pengeluaran riil, jumlah anggota keluarga, wilayah geografi, dan pendidikan ibu rumah tangga secara bersama-sama berpengaruh terhadap proporsi pengeluaran untuk masing-masing produk ikan-ikanan, daging sapi, dan daging ayam.

Nilai $R^{2}$ untuk semua persamaan permintaan dalam penelitian ini berkisar antara 0,147-0,171. Hal ini menggambarkan bahwa $1,47 \%-1,71 \%$ variasi dalam proporsi pengeluaran ikan, daging sapi, dan daging ayam dijelaskan oleh variabel-variabel bebasnya dalam model.

Kecuali pendidikan ibu rumah tangga, semua parameter yang ditemukan dalam pendugaan konsumsi daging sapi secara statistik signifikan dengan taraf signifikansi antara $1 \%-10 \%$. Hal ini mengandung arti bahwa secara parsial harga ikan, harga daging sapi, harga daging ayam, pengeluaran (sebagai proksi pendapatan), wilayah geografi, dan jumlah anggota keluarga berpengaruh signifikan terhadap proporsi pengeluaran untuk produk daging sapi.

Parameter harga daging sapi bertanda positif artinya bahwa semakin mahal harga daging sapi maka proporsi pengeluaran untuk produk ini akan semakin besar. Sementara itu dilihat dari tandanya parameter harga ikan-ikanan dan daging ayam bernilai negatif, artinya semakin mahal harga ikan dan harga daging ayam, maka proporsi pengeluaran untuk produk daging sapi akan semakin kecil.
Dugaan parameter pengeluaran untuk proporsi pengeluaran daging sapi memiliki tanda positif. Hal ini berarti bahwa semakin tinggi pengeluaran riil (atau yang bisa juga dikatakan pendapatan) rumah tangga, maka semakin besar proporsi pengeluaran yang digunakan untuk mengkonsumsi daging sapi.

Berdasarkan hasil estimasi juga ditemukan bahwa ada perbedaan proporsi pengeluaran untuk daging sapi antara rumah tangga di wilayah pedesaan dan perkotaan, sementara proporsi pengeluaran daging sapi ternyata tidak ditentukan oleh tingkat pendidikan ibu rumah tangga. Lebih lanjut hasil estimasi juga menunjukkan bahwa semakin banyak anggota keluarga maka akan semakin besar pula proporsi pengeluaran untuk produk daging sapi.

\section{Elastisitas Permintaan Tiga Bahan Makanan} Sumber Protein Hewani

Elastisitas permintaan menggambarkan derajat kepekaan perubahan permintaan karena adanya perubahan dalam variabel bebasnya sebesar $1 \%$. Dalam penelitian ini akan ditemukan angka koefisien elastisitas harga sendiri (price elasticity of demand), elastisitas harga silang (cross elasticity of demand), dan elastisitas pengeluaran/ pendapatan (income elasticity of demand).

1. Elastisitas Harga (Price Elasticity of Demand)

Besarnya elastisitas harga dihitung dengan pendekatan Marshallian dan Hicksian dengan mengadopsi formula yang disampaikan oleh Fujii, Khaled, dan Mark (1985).

Berdasarkan hasil perhitungan seperti ditampilkan pada tabel 2, elastisitas harga sendiri untuk ketiga 
Tabel 2. Elastisitas Harga Permintaan

\begin{tabular}{lcccc}
\hline \multirow{2}{*}{ Ukuran Elastisitas Permintaan } & Formula & Komoditi \\
\cline { 3 - 5 } & $-1-\beta_{i}+\gamma_{i} / w_{i}$ & -0.39 & $\begin{array}{c}\text { Daging } \\
\text { Ayam }\end{array}$ & Dagung Sapi \\
\hline uncompensated/Marshallian & $-1-w_{i}+\gamma_{i} / w_{i}$ & -0.27 & -0.17 & -0.69 \\
compensated/Hicksian & & & & -0.16 \\
\hline
\end{tabular}

produk bertanda negatif dan memiliki nilai mutlak kurang dari 1 . Hal ini sejalan dengan hukum permintaan yang mendasari perilaku konsumsi yang berarti bahwa bila harga masing-masing barang (daging sapi, daging ayam, dan
Hicksian dengan mengadopsi formula yang disampaikan oleh Fujii, Khaled, dan Mark (1985). Hasil perhitungan elastisitas harga silang ditunjukkan dalam tabel 3. Dari perhitungan di atas tampak bahwa tanda koefisien elastisitas silang antara

Tabel 3. Nilai Elastisitas Harga Silang (Cross Elasticity of Demand)

\begin{tabular}{|c|c|c|c|c|c|c|c|}
\hline \multirow{6}{*}{ 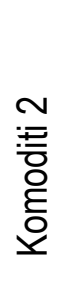 } & \multicolumn{7}{|c|}{ Komoditi 1} \\
\hline & & \multicolumn{2}{|c|}{ Daging Sapi } & \multicolumn{2}{|c|}{ Daging Ayam } & \multicolumn{2}{|c|}{ Ikan } \\
\hline & & UC/M & $\mathrm{C} / \mathrm{H}$ & UC/M & $\mathrm{C} / \mathrm{H}$ & UC/M & $\mathrm{C} / \mathrm{H}$ \\
\hline & Daging Sapi & & & -0.44 & 0.03 & 0.03 & 0.29 \\
\hline & Daging Ayam & -0.38 & 0.01 & & & 0.06 & 0.25 \\
\hline & Ikan & -0.17 & 0.07 & -0.15 & 0.07 & & \\
\hline
\end{tabular}

Keterangan:

UC/M : uncompensated/Marshallian

$\mathrm{C} / \mathrm{H}$ : compensated/Hicksian

ikan-ikanan) naik, maka jumlah yang diminta untuk masing-masing produk tersebut akan berkurang dan sebaliknya. Berdasarkan perhitungan tersebut juga ditemukan bahwa permintaan ketiga barang bersifat inelastis atau tidak peka terhadap perubahan harga.

2. Elastisitas Harga Silang (Cross Elasticity of Demand)

Besarnya elastisitas harga silang dihitung dengan pendekatan Marshallian dan produk satu dengan yang lain bervariasi positif dan negatif. Hal ini berarti bahwa produk daging sapi, daging ayam dan ikan-ikanan bisa saling mensubstitusi ataupun saling melengkapi satu dengan yang lainnya.

3. Elastisitas Pengeluaran/Pendapatan (Income Elasticity of Demand).

Besarnya elastisitas harga silang dihitung dengan pendekatan Marshallian dan Hicksian dengan mengadopsi formula

Tabel 4. Nilai Elastisitas Harga Silang (Cross Elasticity of Demand)

\begin{tabular}{ccccc}
\hline Ukuran Elastisitas & Formula & Ikan & $\begin{array}{c}\text { Domoditi } \\
\text { Ayam }\end{array}$ & $\begin{array}{c}\text { Daging } \\
\text { Sapi }\end{array}$ \\
\hline Pengeluaran/Pendapatan & $1+\beta_{i} / w_{i}$ & 0,57 & 1,03 & 1,38 \\
\hline
\end{tabular}


yang disampaikan oleh Fujii, Khaled, dan Mark (1985).

Hasil perhitungan elastisitas pendapatan untuk produk-produk dalam penelitian ini ditampilkan dalam tabel 4. Dari perhitungan di atas tampak bahwa tanda koefisien elastisitas pendapatan semua produk bertanda positif. Hal ini berarti bahwa apabila pendapatan konsumen meningkat maka jumlah daging sapi, daging ayam dan ikan-ikanan yang diminta konsumen akan meningkat pula.

\section{Estimasi Permintaan Bahan Makanan \\ Sumber Protein Hewani}

Hasil temuan menunjukkan bahwa estimasi permintaan untuk tiga macam barang yang diteliti (ikan, daging ayam, dan daging sapi) memiliki pola yang cenderung serupa. Secara bersama-sama variabel-variabel bebas dalam penelitian yaitu harga barang sendiri, harga barang lain, pengeluaran rumah tangga, jumlah anggota keluarga, pendidikan ibu rumah tangga dan wilayah geografi berpengaruh terhadap proporsi pengeluaran untuk masing-masing barang.

Tanda untuk parameter harga sendiri pada ketiga barang bertanda positif. Hal ini berarti bahwa apabila harga ikan naik maka proporsi pengeluaran untuk ikan akan naik, apabila harga daging sapi naik maka proporsi pengeluaran untuk daging sapi akan naik, dan apabila harga daging ayam naik, maka proporsi pengeluaran untuk daging ayam juga akan naik. Pada umumnya apabila harga suatu barang naik, maka akan diikuti dengan penurunan jumlah yang diminta atau penurunan proporsi pengeluaran untuk produk yang bersangkutan. Untuk produkproduk dalam penelitian ini, penjelasan yang rasional dapat dikaitkan dengan nilai elastisitas harga sendiri. Ditemukan bahwa permintaan ketiga barang bersifat in elastis. Hal ini mengindikasikan bahwa apabila terjadi perubahan harga, maka tidak akan mengubah jumlah yang diminta dalam jumlah banyak, sehingga proporsi pengeluaran untuk produk yang bersangkutan juga tidak berubah banyak. Dengan demikian kenaikan harga ikan atau daging ayam atau daging sapi dengan catatan permintaan barang tersebut bersifat in elastis (sehingga jumlah yang diminta cenderung tetap) akan menghasilkan kenaikan proporsi pengeluaran untuk masing-masing barang.

Tanda untuk parameter harga barang lain dalam setiap model bertanda negatif. Beberapa implikasi yang bisa ditarik yaitu apabila harga daging ayam atau daging sapi naik maka proporsi pengeluaran untuk ikan akan turun, sedangkan apabila harga ikan atau harga ayam naik maka proporsi pengeluaran untuk daging sapi akan turun, dan lebih lanjut bila harga ikan dan daging ayam naik maka proporsi pengeluaran untuk daging ayam akan turun. Tanda parameter harga barang lain yang sama dalam setiap model menggambarkan bahwa preferensi rumah tangga dalam mengkonsumsi berbagai variasi makanan sumber protein hewani cenderung konsisten, bahwa produkproduk tersebut bisa saling mensubstitusi satu dengan yang lain.

Variabel pengeluaran untuk daging sapi dan daging ayam memiliki tanda positif sedangkan untuk ikan-ikanan bertanda negatif. Perlu diingat bahwa pengeluaran di sini adalah pengeluaran total, sehingga sangat bisa dimengerti bahwa pada saat 
pengeluaran total meningkat, maka tambahan pengeluaran itu akan digunakan untuk menambah proporsi pengeluaran untuk daging sapi dan daging ayam. Sementara itu ketika pengeluaran total meningkat, maka proporsi pengeluaran untuk ikan akan berkurang, karena dimungkinkan rumah tangga mensubstitusinya dengan produk yang lain.

Meskipun dengan taraf signifikansi yang besar (90\%) ditemukan bahwa wilayah geografi berpengaruh terhadap proporsi pengeluaran untuk baik produk ikan, daging sapi, maupun daging ayam. Hal ini berarti ada perbedaan preferensi konsumsi ikan-ikanan, daging ayam, dan daging sapi antara rumah tangga di wilayah perdesaan dan perkotaan. Preferensi rumah tangga di wilayah perkotaan cenderung pada produk ikan dan daging sapi, sedangkan untuk rumah tangga di wilayah perdesaan cenderung memilih daging sapi.

Parameter penduga jumlah anggota keluarga untuk produk daging sapi dan ikan signifikan sedangkan untuk daging ayam tidak signifikan. Hal ini berarti bahwa jumlah keluarga tidak berpengaruh terhadap proporsi pengeluaran daging ayam. Sementara itu parameter yang ditemukan untuk daging sapi bertanda negatif sedangkan untuk ikan bertanda positif. Hal ini berarti bahwa semakin banyak anggota keluarga maka akan semakin sedikit proporsi pengeluaran untuk daging sapi tetapi akan semakin banyak untuk ikan-ikanan. Berkurangnya proporsi pengeluaran daging sapi dengan semakin banyaknya jumlah anggota keluarga diduga berkaitan dengan harga daging sapi yang relatif mahal, sehingga dengan semakin banyaknya anggota keluarga membuat rumah tangga akan memilih mengkonsumsi produk lain yang harganya lebih murah. Untuk produk ikan mudah sekali untuk dimengerti bahwa semakin banyak anggota keluarga, maka kebutuhan ikan untuk konsumsi akan semakin banyak, sehingga proporsi pengeluaran untuk produk ikan-ikanan juga akan semakin besar.

Di luar dugaan tingkat pendidikan ibu rumah tangga tidak berpengaruh terhadap proporsi pengeluaran bahan makanan sumber protein hewani. Perlu diketahui bahwa tingkat pendidikan dalam penelitian ini adalah capaian pendidikan formal ibu rumah tangga dan bukan pemahamannya yang baik mengenai manfaat bahan makanan sumber protein hewani bagi kesehatan anggota keluarga, meskipun pada awal penelitian ini diharapkan capaian pendidikan formal merupakan proksi yang baik untuk pemahaman mengenai bahan pangan yang bermanfaat bagi kesehatan anggota keluarga.

Untuk semua model dalam penelitian ini ditemukan bahwa nilai $\mathrm{R}^{2}$ relatif kecil, berkisar antara $0,147-0,171$. Nilai $R^{2}$ yang rendah memang biasa terjadi pada penelitian yang berbasis pada data rumah tangga, karena banyaknya sampel yang diambil sehingga variasi perilaku konsumsi pada sampel rumah tangga tersebut banyak yang tidak terwakili oleh variabel yang digunakan dalam penelitian ini, misalnya umur, jenis kelamin anggota keluarga, agama, adat istiadat, status sosial, kondisi demografi dan lain sebagainya. 


\section{Elastisitas Permintaan Bahan Makanan Sumber Protein Hewani}

Elastisitas harga sendiri (price elasticity of demand) untuk ketiga barang dalam penelitian ini sesuai teori bertanda negatif, yang artinya bila harga ikan, atau daging sapi atau daging ayam naik maka jumlah barang yang diminta akan berkurang. Sifat elastisitas ketiganya adalah in elastis karena memiliki nilai elastisitas dalam harga mutlak kurang dari 1, di mana di antara ketiganya, permintaan daging sapi paling elastis, diikuti daging ayam dan ikan. Sifat permintaan bahan makanan sumber protein nabati yang in elastis bisa dimengerti karena ketiga barang merupakan produk yang penting/pokok untuk memenuhi kebutuhan konsumen, sehingga perubahan harga tidak terlalu direspon konsumen dengan mengurangi/menambah jumlah yang diminta secara signifikan. Daging sapi lebih elastis dibanding daging ayam dan ikan, karena harga daging sapi paling mahal dibanding daging ayam dan ikan. Hal ini sesuai dengan teori bahwa semakin mahal harga suatu barang relatif terhadap pendapatan konsumen maka akan semakin elastis permintaan barang tersebut.

Dengan pendekatan Marshallian ditemukan bahwa elastisitas silang antara daging sapi, daging ayam, dan ikan bervariasi antara nilai positif ataupun negatif. Hal ini mengandung arti bahwa hubungan antara ketiga barang bisa saling melengkapi ataupun saling mensubstitusi. Daging sapi dan daging ayam bisa mensubstutusi ikan, daging sapi dan ikan bisa melengkapi daging ayam, dan daging ayam dan ikan bisa melengkapi daging sapi. Tanda koefisien elastisitas silang yang terkadang positif atau negatif diduga karena dalam penelitian ini tidak dilakukan pengelompokkan rumah tangga berdasarkan besarnya pendapatan rumah tangga. Pada umumnya untuk kelompok rumah tangga dengan pendapatan tinggi antar ketiga barang bisa bersifat saling melengkapi, sedangkan untuk kelompok rumah tangga dengan penghasilan rendah, hubungan penggunaan antara ketiga barang cenderung saling mensubstitusi. Adanya hasil yang mengindikasikan bahwa antar bahan pangan bersifat saling melengkapi sejalan dengan hasil penelitian yang dilakukan oleh Kim Budiwinarto (2002).

Elastisitas pengeluaran/pendapatan (income elasticity of demand) ketiga barang dalam penelitian ini bertanda positif. Hal ini berarti bahwa bila pendapatan naik maka rumah tangga akan menambah jumlah daging sapi atau daging ayam atau ikan yang dikonsumsi. Berturut-turut elastisitas pendapatan untuk daging sapi, daging ayam, dan ikan-ikanan adalah 1,38; 1,03; dan 0,57. $\mathrm{Hal}$ ini sangat logis mengingat bila dilihat dari harga rata-rata ketiga jenis barang tersebut harga daging sapi adalah yang paling tinggi, diikuti harga daging ayam dan ikan. Dengan kata lain di antara ketiga jenis barang tersebut, daging sapi adalah makanan sumber protein hewani yang paling responsif terhadap perubahan pengeluaran/ pendapatan. Nampak bahwa elastisitas pendapatan untuk daging sapi dan daging ayam lebih besar dari 1 (elastis) sehingga respon permintaan kedua barang ini sangat peka terhadap perubahan pendapatan dalam arti kenaikan pendapatan konsumen sebesar $1 \%$ akan menambah jumlah kedua barang tersebut yang diminta lebih dari $1 \%$ dan sebaliknya. Sementara itu kenaikan 
pendapatan konsumen sebesar 1\% akan menambah jumlah ikan yang diminta sebesar $0,57 \%$ dan sebaliknya.

\section{SIMPULAN}

Secara parsial harga ikan, harga daging sapi, pengeluaran (sebagai proksi pendapatan) rumah tangga, wilayah geografi, dan jumlah anggota keluarga berpengaruh terhadap pangsa pengeluaran untuk produk ikanikanan. Secara parsial harga ikan, harga daging sapi, harga daging ayam, pengeluaran (sebagai proksi pendapatan) rumah tangga, wilayah geografi, dan jumlah anggota keluarga berpengaruh signifikan terhadap proporsi pengeluaran untuk produk daging sapi. Secara parsial harga ikan, harga daging sapi, harga daging ayam, dan wilayah geografi, berpengaruh signifikan terhadap proporsi pengeluaran untuk produk daging ayam. Secara bersama-sama variabelvariabel bebas dalam penelitian yaitu harga barang sendiri, harga barang lain, pengeluaran rumah tangga, jumlah anggota keluarga, pendidikan ibu rumah tangga dan wilayah geografi berpengaruh terhadap proporsi pengeluaran untuk ikan, daging sapi dan daging ayam. Elastisitas harga sendiri untuk ikan, daging sapi, dan daging ayam bertanda negatif dan bersifat in elastis. Daging sapi dan daging ayam merupakan substitusi untuk ikan. Daging sapi dan ikan merupakan barang komplementer untuk daging ayam. Daging ayam dan ikan merupakan barang komplementer untuk daging sapi. Berturut-turut elastisitas pendapatan untuk daging sapi, daging ayam, dan ikan-ikanan adalah 1,38; 1,03; dan 0,57.

\section{Ucapan Terima Kasih:}

Penulis mengucapkan terima kasih kepada peserta seminar proposal maupun hasil yang telah memberikan berbagai masukan untuk penelitian ini, dan FE-UNY atas pendanaan yang diberikan untuk penelitian ini dengan sekama dana DIPA FE-UNY.

\section{DAFTAR PUSTAKA}

Bank Indonesia. (2011). Analisis Sensitivitas Konsumsi Rumah Tangga terhadap PDB dan Pengaruh Inflasi terhadap Pola Konsumsi, Bank Indonesia

Deaton, A., \& Muellbauer, J. (1980). An almost Ideal Demand System. American Economic Review. 70. 312-326.

Fujii, E. T., Khaled, M., \& Mark, J. (1985). An almost Ideal Demand System for Visitor Expenditures. Journal of Transport Economics and Policy, 19, 161-171.

Kim Budiwinarto. (2002). Penerapan model Almost Ideal Demand System (AIDS) pada Pola Konsumsi Pangan Rumah Tangga Nelayan di Kecamatan Tambak Kabupaten Banyumas, www.unsa.ac.id/ ejournal/ diunduh tanggal 20 Maret 2013

Rusfidra. (2013) Urgensi Protein Hewani untuk Kecerdasan. http://www. bunghatta.ac.id/artikel/120/ diunduh tanggal 20 Maret 2013

Statistik Indonesia berbagai penerbitan 